\title{
GOD SERVANTS' KNOWLEDGE AND STIGMA OF TUBERCULOSIS IN KUPANG INDONESIA
}

\author{
Imelda F. E. Manurung ${ }^{1 *}$, Luh Putu Ruliati ${ }^{1}$, Helga J.N. Ndun ${ }^{1}$, Aminah H. Baun ${ }^{2}$, Yumiati Ke \\ Lele $^{3}$, Chatarina U. Wahyuni ${ }^{4}$ \\ ${ }^{1}$ Public Health Faculty, Nusa Cendana University, Kupang \\ ${ }^{2}$ East Nusa Tenggara Provincial Health Office \\ ${ }^{3}$ Health Office of Kupang City \\ ${ }^{4}$ Department of Epidemiology, Airlangga University, Surabaya
}

Received: 3 July 2018 | Revised: 16 July 2018 | Accepted: 23 July 2018

*Correspondence:

Imelda F.E. Manurung

Jl. Adisucipto, Penfui, Kampus FKM UNDANA Kupang

Phone/HP: 081237999910

E-mail: ifem holland@yahoo.com

Copyright: (C) the author(s), YCAB publisher and Public Health of Indonesia. This is an open-access article distributed under the terms of the Creative Commons Attribution Non-Commercial License, which permits unrestricted non-commercial use, distribution, and reproduction in any medium, provided the original work is properly cited.

\begin{abstract}
Background: Knowledge and stigma are the factors that determine the success of TB control. The people of East Nusa Tenggara still rely heavily on the support of God's servants in addressing health issues. God's servant is someone who is believed to have the gift of healing through prayer to the Lord Jesus.

Aim: This study aimed to reveal God's servants' knowledge on and stigma to TB.

Methods: This study is a descriptive quantitative study, in which the research aims to perceive God's servants' knowledge and stigma to TB in 2 community health centers with the most TB cases in Kupang. The population of the study was God's servants in three areas of coverage of community health centers with the most TB cases. The sample of the study was the entire population (Total sampling) as many as 120 people. Data were collected through questionnaires and using mid-point score.

Results: The results showed that the knowledge related to transmission, treatment, and prevention of Tuberculosis was low, amounted to $76 \%$, similar to the stigma to TB that was amounted to $58 \%$. God's servants still held the stigma that TB is a curse and disgraceful disease and they were unwilling to share with tuberculosis patients.

Conclusion: God's servants' knowledge related to TB is low. As for stigma, even though mostly is low, there are still many God's servants who give stigma to TB disease. Since God's servant is a potential figure believed by some people to have the gift of healing, their knowledge and stigma needs to be improved in order to provide true information and support for TB patients.
\end{abstract}

Keywords: knowledge, stigma, God's servant, tuberculosis

\section{INTRODUCTION}

Indonesia is ranked the second country with the most TB cases in the world. In 2015, it was reported that the number of TB cases reached 330.910 cases and was estimated to increase to 460.000 by 2017 (WHO, 2016). Likewise in East Nusa Tenggara, there was an increase in TB cases by 6.354 in 2016 compared to 4.485 cases in 2015. In 2015, new TB cases were found in 10 per 100,000 populations. However, in 2016, the number increased to 15 per 100.000 populations. One of the indicators to measure the success of the pulmonary tuberculosis program is cure rate with annual target of $90 \%$. In 2015, the cure rate was $66.30 \%$ and in 2016 the number decreased to $52.81 \%$. It shows that in 2016 , there was a 
decrease in the number of patients with BTA+ pulmonary TB who had been recovered, and every year until now, the cure rate has never reached the target of the strategic plan. Similarly, the success rate only reached $87.9 \%$, whereas the national target is $100 \%$. The highest cure rate is in Central Sumba Regency (97.30\%), followed by Sabu Raijua Regency ( $88.57 \%$ ), while the lowest is in Kupang (28\%.) The highest success rate is in Malaka regency with $100 \%$, followed by TTU regency with $72.99 \%$, while the lowest is in Kupang with $71.93 \%$ (DinKes Propinsi NTT, 2016).

The failure of TB control is due to the embarrassment and lack of family and community support (Finlay et al., 2012). Stigma is also a factor often experienced by TB patients where they will be excommunicated because the disease can spread to others (Diefenbach-Elstob et al., 2017). Local support is the potential and resources possessed by an area to be used to achieve goal (Davtyan et al., 2015). God's servant is an informal leadership figure that lives and develops among the East Nusa Tenggara community. God's servants become a potential figure in East Nusa Tenggara as they contribute to the solving of health issues in the community (Manurung, U.W, \& Probandari, 2016).

Most of the East Nusa Tenggara population is very dependent on God's servants other than the health workers because God's servants' ideas, words and behavior are role models. God's servant is a person who is believed to have the gift of healing and be able to help individuals overcome the struggles of life. Some of East Nusa Tenggara population, especially those in remote areas, sees TB as a disease due to mystical things. To seek for cure, people commonly see God's servant in order to be prayed for. They will do anything the God's servant tells them to. Research conducted by (Manurung et al., 2016) shows that God's servant's health literacy and perception have a great influence on the social support they provide to individuals at risk for HIV and AIDS to do VCT. This research is important in revealing God's servants' knowledge on and stigma to Tuberculosis because people in East Nusa Tenggara seek for cure to God's servants.

\section{METHODS}

\section{Study design}

This research is descriptive quantitative study. The study population was all God's servants in the area of three community health centers with the most TB cases in Kupang i.e. Sikumana, Bakunase and Oesapa. God's servant is someone who is believed by community to have the gift of healing illness and may be any religion. Information about how many God's servants in the study site were obtained from community.

\section{Sample}

The total population of God's servants was 120 people. The inclusion criteria of the sample were God's servants who actively serve sick people at least 10 people in one month. The number of samples being the respondents of the study was the entire population (total sampling).

\section{Instrument}

The instrument used questionnaire in this study was the modified instruments used by Jittimanee et. al (Jittimanee et al., 2009) to measure stigma to patients with tuberculosis in Thailand. Data were collected through interview. Stigma and knowledge variables use different questionnaires. Questionnaire containing knowledge about $\mathrm{TB}$, risk factors for transmission and prevention. The stigma questionnaire was asked first before the knowledge. Each questionnaire is asked to the respondent and written by the researcher. The knowledge variable consisted of 7 items of questions related to the definition, symptoms, transmission, prevention and treatment of TB. A value of 1 was given when the answer was correct and the value of 0 was given when the answer was wrong. The stigma variable was a statement with 2 choices, the value of 0 was given when the respondent chose agree and the value of 1 was given when the 
respondent chose disagree. The score range of this instrument ranges from 0-7. The measurements of this instrument are high and low knowledge and high and low stigma. The analysis technique used the mid-point of the total score of the instrument; the maximum value was reduced by the minimum value and then divided by two. The mid point score in this study was 3.5. Therefore, the knowledge as well as the stigma was considered to be low when the score was lower than 3.5.

\section{Data analysis}

A percentage statistical analysis was used to obtain a description of the frequency distribution of the variables studied.
Ethical consideration

Ethical clearance was obtained from the Faculty of Medicine Nusa Cendana University, Indonesia. A written informed consent was received from all God's servants. The researcher maintained the confidentiality of respondents' identity, other identifying information.

\section{RESULTS}

Based on the results of the study, Table 1 shows that the most characteristics of the respondents were housewife, Christian, and having been God's servant for more than 5 years.

Table 1 Distribution of God's Servants Based on Characteristics, Knowledge and Stigma to TB in Kupang 2017

\begin{tabular}{|c|c|c|}
\hline \multirow{2}{*}{ Characteristics } & \multicolumn{2}{|c|}{ Frequency } \\
\hline & $\mathbf{n}=\mathbf{1 2 0}$ & $\%$ \\
\hline \multicolumn{3}{|l|}{ Respondents } \\
\hline Gender, \% male & 58 & 48.3 \\
\hline Religion, \% Christian & 85 & 70.8 \\
\hline Age, $\%<40$ years & 38 & 31.7 \\
\hline Occupation, \% employee & 59 & 49.2 \\
\hline Education, \% bachelor or higher & 71 & 59.2 \\
\hline Period of service as a God's servant; $\%>=5$ years & 92 & 76.7 \\
\hline \multicolumn{3}{|l|}{ Knowledge on TB (Respondent with correct answer; $n=120$ ) } \\
\hline TB is a disease caused by witchcraft & 50 & 41.7 \\
\hline A person with TB can be cured & 89 & 74.2 \\
\hline Coughing for more than 2 weeks is one of the symptoms of TB & 45 & 37.5 \\
\hline TB may lead to death if patient fails to take medication regularly & 42 & 35.0 \\
\hline TB can be transmitted through cutlery & 32 & 26.7 \\
\hline TB transmission can be prevented if TB patients do not cough up sputum carelessly. & 38 & 31.7 \\
\hline TB patients may stop taking the medication when they are getting better & 50 & 41.7 \\
\hline \multicolumn{3}{|l|}{ Stigma (number of respondents withsStigma; $n=120$ ) } \\
\hline $\mathrm{TB}$ is a curse & 86 & 71.7 \\
\hline $\begin{array}{l}\text { If one of my family members suffers from } \mathrm{TB} \text {, I do not mind sharing my cutlery with } \\
\mathrm{him} / \mathrm{her}\end{array}$ & 83 & 69.2 \\
\hline I am ashamed if one of my family members suffers from TB & 89 & 74.2 \\
\hline I do not want to share a bed with a person taking TB treatment & 87 & 72.5 \\
\hline TB is the illness of the poor & 65 & 54.2 \\
\hline People with TB should be isolated & 83 & 69.2 \\
\hline TB sufferers are a disgrace to the society & 84 & 70 \\
\hline \multicolumn{3}{|l|}{ Category } \\
\hline Knowledge on TB (Good) & 42 & 35 \\
\hline Stigma (High) & 82 & 68 \\
\hline
\end{tabular}

The results showed that the most respondents had their answer wrong to the statement that TB can be transmitted through sharing cutlery (73.3\%). On the other hand, most of the respondents had their answer correct to the statement that TB can be cured $(74.2 \%)$. The most stigma was given to the statement 'I am ashamed if one of my family members suffers from TB'. The least stigma was given to the statement 'TB is the illness of the poor'. Based on the category of mid-point value, it was obtained that as many as 78 God's servants $(65 \%)$ had lower knowledge on TB. As for the stigma, 82 God's servants $(68 \%)$ were categorized as having high stigma. 


\section{DISCUSSION}

The knowledge of God's servants is still poor due to the lack of access to information about TB (Dewi, Barclay, Passey, \& Wilson, 2016). Several factors that affect the poor knowledge can be caused by the lack of socialization of TB and the limited media of TB related information in reaching various communities in society, especially the community of God's servants (Tadesse, 2016). This community is influential for people who need prayer service because it is believed to have the gift of curing illness through the power of prayer (Paul et al., 2015). There are many people in NTT who still use God's servant's prayer to support healing.

God's servant is very trusted and able to influence his patients to stay strong (Stewart, 2014). People who use prayer service from God's servant will honestly answer every question and will follow the advice proposed by the God's servant. Health education for God's servants, particularly on $\mathrm{TB}$, is very important because the aim of the prayer service given is to cure illness (Craig, Daftary, Engel, O'Driscoll, \& Ioannaki, 2017). God's servant with poor knowledge will influence the intervention provided for individuals who are suspected to have and infected with TB. According to God's servants' confession, they once gave advice for people infected with TB to stop taking medicine because they believed that the illness had healed through prayer. God's servants who have a thorough knowledge on TB treatment will certainly motivate TB patients to regularly take medicine (Eriksson, Lindmark, Haddad, \& Axemo, 2014). God's servants who have a proper knowledge on TB will be a supporting factor for the recovery of TB patients. On the other hand, God's servants who have poor knowledge on TB can be an inhibiting factor in the recovery process of TB patients (Williams, Glanz, Kegler, \& Davis, 2012).

The results showed that there were still many God's servants who had TB related stigma. Stigma is one of the social determinants that can cause health issues too late to be addressed (Diefenbach-Elstob et al.,
2017). God's servants who had a stigma to TB once advised a family to isolate TB patients. Yet, the God's servants were still willing to provide prayer service to $\mathrm{TB}$ patients. The concept of their service is the service of love. Although they have a stigma to TB patients, they are still willing to serve them (Williams et al., 2012). The service given by God's servants will definitely support the service given by Community Health Centre if God's servants have a proper knowledge and do not give stigma.

\section{CONCLUSION}

God's servant as a figure of local wisdom potential for addressing health issues can support TB control if they are well informed and do not give stigma. Therefore, efforts to improve their knowledge through various communication media are necessary.

\section{REFERENCES}

Craig, G., Daftary, A., Engel, N., O’Driscoll, S., \& Ioannaki, A. (2017). Tuberculosis stigma as a social determinant of health: a systematic mapping review of research in low incidence countries. International Journal of Infectious Diseases, 56, 90-100.

Davtyan, K., Aghabekyan, S., Davtyan, H., Margaryan, T., Zachariah, R., Acosta, C., ... Hayrapetyan, A. (2015). Social Support Programme For Tuberculosis Patients in Armenia: Perceptions of Patients and Doctors. Public Health Panorama.

Dewi, C., Barclay, L., Passey, M., \& Wilson, S. (2016). Improving knowledge and behaviours related to the cause, transmission and prevention of Tuberculosis and early case detection: a descriptive study of community led Tuberculosis program in Flores, Indonesia. BMC public health, 16(1), 740 .

Diefenbach-Elstob, T., Plummer, D., Dowi, R., Wamagi, S., Gula, B., Siwaeya, K., ... Warner, J. (2017). The social determinants of tuberculosis treatment adherence in a remote region of Papua New Guinea. BMC public health, 17(1), 70.

DinKes Propinsi NTT. (2016). Profil Kesehatan Nusa Tenggara Timur. Kupang: Dinas Kesehatan Provinsi Nusa Tenggara Timur.

Eriksson, E., Lindmark, G., Haddad, B., \& Axemo, P. (2014). Young people, sexuality, and HIV prevention within Christian faith communities 
in South Africa: A cross-sectional survey. Journal of religion and health, 53(6), 16621675.

Finlay, A., Lancaster, J., Holtz, T. H., Weyer, K., Miranda, A., \& van der Walt, M. (2012). Patient-and provider-level risk factors associated with default from tuberculosis treatment, South Africa, 2002: a case-control study. BMC public health, 12(1), 56.

Jittimanee, S. X., Nateniyom, S., Kittikraisak, W., Burapat, C., Akksilp, S., Chumpathat, N., . . . Varma, J. K. (2009). Social stigma and knowledge of tuberculosis and HIV among patients with both diseases in Thailand. PLoS One, 4(7), e6360.

Manurung, I. F. E., U.W, C., \& Probandari, A. (2016). Effect of Health Literacy to the Empowered Servant of God in Supporting Individuals at Risk of HIV and AIDS to Follow VCT. International Journal of Sciences: Basic and Applied Research, 26(1), 231-236.

Paul, S., Akter, R., Aftab, A., Khan, A. M., Barua, M., Islam, S., . . . Sarker, M. (2015). Knowledge and attitude of key community members towards tuberculosis: mixed method study from
BRAC TB control areas in Bangladesh. BMC public health, 15(1), 52.

Stewart, J. M. (2014). Pastor and lay leader perceptions of barriers and supports to HIV ministry maintenance in an African American church. Journal of religion and health, 53(2), 317-325.

Tadesse, S. (2016). Stigma against tuberculosis patients in Addis Ababa, Ethiopia. PLoS One, 11(4), e0152900.

WHO. (2016). Use of high burden country lists for TB by WHO in the post-2015 era. Geneva: World Health Organization.

Williams, R. M., Glanz, K., Kegler, M. C., \& Davis, E. (2012). A study of rural church health promotion environments: Leaders' and members' perspectives. Journal of religion and health, 51(1), 148-160.

Cite this article as: Manurung, I. F. E., Ruliati, L. P., Ndun, H. J. N., Baun, A. H., Lele, Y. K., Wahyuni, C. U. (2018). God servants' knowledge and stigma of tuberculosis in Kupang Indonesia. Public Health of Indonesia, 4(3):116-120. 